Original article

\title{
REINSTATING GREEK E-GOVERNANCE: A FRAMEWORK FOR E-GOVERNMENT BENCHMARKING, IMPROVEMENT AND GOVERNMENT POLICIES
}

\author{
Georgios Kontogeorgis', Nikolaos Varotsis² \\ ${ }^{1,2}$ Ionian University, Tourism Department, Corfu, Greece. \\ Address: Building "Calypso", P. Vraila Armeni 4, 49100 Corfu, Greece.

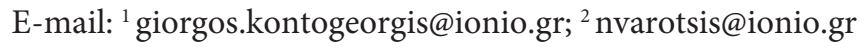

\begin{abstract}
This paper presents the implementation and evolution of e-governance in Greece as well as offering insights, policies and suggestions for the design of e-government benchmarks. The research objectives of this article are to identify the appraisal of Greece in e-government over time and in relation to other countries as well as the role of internal audit and transparency related to digital public services. The method adopted is through an extensive bibliographic review of the Greek, European and international literature of the thematic field of e-government as well as the presentation of several frameworks to structure the discussion of e-government benchmark design based on a benchmarking with key indicators of published surveys from internationally reputable organizations. The findings of this paper are that Greece proceeded at a very slow pace in its digital transformation, shows shortcomings in e-government policies, records delays in adapting the services requested by citizens, and no matter the lack of investment in technological infrastructure, the effectiveness of e-governance presupposes proactiveness. Nevertheless, another key conclusion of the research is that Greece is far from the average performance of e-government in the European Union due to its chronic economic problems, the lack of technological equipment and the lack of overall orientation in e-government. Furthermore, this paper can be a measure of comparison for other countries that have similar characteristics to Greece in order to improve e-governance.
\end{abstract}

Keywords: e-governance, public administration, benchmarking, transparency, organizational behavior, internal audit.

For citation: Kontogeorgis, G. and Varotsis, N. (2021) 'Reinstating Greek e-governance: A framework for e-government benchmarking, improvement and government policies', Public Administration Issues, 6 (Special Issue II, electronic edition), pp. 103-127 (in English). DOI: 10.17323/1999-5431-2021-0-6-103-127. 


\section{Introduction}

Nowadays, the spread of technology is practically huge. Some typical examples of the use of technology are the fact that there are 4.39 billion unique internet users and 3.48 billion social network users (Datareportal Digital, 2019). The evolution and dissemination of technology has provided a valuable tool for any government to pursue a more effective government policy.

The use of technology is particularly important for public administration. As a result, the term e-government or digital governance has been developed. The financial programs of the European Union gave an important impetus to the development of digital governance in Greece (Markellos et al., 2014).

The reasons why new technologies have not been sufficiently disseminated in Greece can be divided into three categories. Policy failures, planning and programming weaknesses, and obstacles to the application of new technologies (Tsakanikas et al., 2014). Politicians fail to promote new technologies due to lack of political will, lack of funding programs, lack of state continuity and lack of know-how.

The lack of planning and programming in the public sector is due to the complexity of public sector systems (Murphy et al., 2017), the lack of operating standards of information systems, the network problems and the technical weaknesses of the systems. Finally, obstacles to the implementation of new technologies in the public sector are the high cost of purchasing information systems and software, the complexity of information systems, the lack of monitoring of the implementation of new technologies, the lack of executives to implement the new technologies and the lack of incentives to implement of new technologies (Glyptis et al., 2020).

The article includes the definition and the importance of e-governance, the meaning of public administration with emphasis on the Greek public administration, the organizational structure and organizational behavior of the Greek public administration, the role of internal audit in e-government, the evolution of e-government governance in Greece and Greece's position in the field of e-government in Europe. Finally, the last section of the article presents the conclusions.

Exploring the degree of e-government establishment and transformation (Pedersen, 2018) in Greece as well as its benchmarking are the main concerns of this research. The knowledge of the operation of Greek public administration, the benchmarking of e-government dimensions and the required government policies are the main purposes of this research.

\section{E-governance}

\subsection{Definitions}

Internet use is increasing day by day and can play an important role in people's daily lives. The concept of e-governance is very popular and is often mentioned by many governments. It is often linked to the use of the internet (Singh, 2020). However, it is a broader concept. 
"Digital governance is the practice of establishing and implementing policies, procedures, and standards for the proper development, use and management of the info sphere" (Floridi, 2018). Dawes (2008) considers that "E-government comprises information and communication technologies (ICTs) to support public services, government administration, democratic process, and relationships among citizens, civil society, the private sector and the state". From the above definition it becomes clear that digital governance plays an important role in the citizen-state relations and in the quality of the services provided by the state. E-government has the potential to change state services to citizens, private and public sector relations and state-to-citizen relations (Markellos et al., 2014).

\subsection{The importance of digital governance}

E-governance is very important for the modern state. Some benefits of digital governance are, according to Erkut (Erkut, 2020), the reduction of bureaucracy, the participation of citizens in decisions through digital processes, the protection of human's rights and the increase of transparency. The separation of the three dimensions of e-government and the six categories of e-government benefits was completed after the study of 53 content analysis articles (Twizeyimana and Andersson, 2019).

The benefits of e-government could be divided into three dimensions.

Table 1

The benefits of e-government

\begin{tabular}{|l|l|l|}
\hline \multicolumn{1}{|c|}{ E-administration } & \multicolumn{1}{|c|}{ E-services } & \multicolumn{1}{c|}{ E-citizens and society } \\
\hline $\begin{array}{l}\text { Improvement of public } \\
\text { administration }\end{array}$ & Improving state services & $\begin{array}{l}\text { Creating moral values } \\
\text { and social benefit }\end{array}$ \\
\hline $\begin{array}{l}\text { Informing citizens about } \\
\text { administrative actions }\end{array}$ & $\begin{array}{l}\text { Increasing the credibility } \\
\text { of the state }\end{array}$ & $\begin{array}{l}\text { Increasing the credibility } \\
\text { of the state }\end{array}$ \\
\hline $\begin{array}{l}\text { Improving the ethical conduct } \\
\text { of civil servants }\end{array}$ & $\begin{array}{l}\text { Informing citizens about } \\
\text { administrative actions }\end{array}$ & \\
\hline
\end{tabular}

Source: Twizeyimana and Andersson (2019).

The Table 2 below shows the benefits of e-governance in a more detailed view.

Table 2

The benefits of digital governance

\begin{tabular}{|l|l|}
\hline \multicolumn{1}{|c|}{ Improvement } & \multicolumn{1}{c|}{ Results } \\
\hline $\begin{array}{l}\text { Improvement of public } \\
\text { services }\end{array}$ & $\begin{array}{l}\text { - More and better services; } \\
\text { - Improving service delivery; } \\
\text { - More and more integrated services }\end{array}$ \\
\hline $\begin{array}{l}\text { Improvement } \\
\text { of management } \\
\text { efficiency }\end{array}$ & $\begin{array}{l}\text { - Cost reduction; } \\
\text { - Reduce corruption and the costs involved; } \\
\text { - Increase the efficiency and effectiveness of operations; } \\
\text { - Reducing administrative burdens }\end{array}$ \\
\hline
\end{tabular}




\begin{tabular}{|c|c|}
\hline Improvement & Results \\
\hline $\begin{array}{l}\text { Opportunities } \\
\text { for open government }\end{array}$ & $\begin{array}{l}\text { - Increase transparency; } \\
\text { - Increasing citizens' control over the administration; } \\
\text { - Increasing participation among public bodies; } \\
\text { - Increasing citizens' participation in public affairs (Alexopoulos et al, 2015) }\end{array}$ \\
\hline $\begin{array}{l}\text { Improving ethical } \\
\text { behavior and } \\
\text { professionalism }\end{array}$ & $\begin{array}{l}\text { - Good use of public money; } \\
\text { - Increase compliance with legislation; } \\
\text { - Spreading the democratic spirit; } \\
\text { - Understanding the value of collaboration; } \\
\text { - Increasing accountability, honesty and moral values }\end{array}$ \\
\hline $\begin{array}{l}\text { Increasing the prestige } \\
\text { and trust of the public } \\
\text { administration }\end{array}$ & $\begin{array}{l}\text { - Better access of citizens to state decisions; } \\
\text { - More and better services; } \\
\text { - Increasing the transparency of the operation of the public administration; } \\
\text { - Better management of public bodies; } \\
\text { - Improving public services and increasing citizens' satisfaction }\end{array}$ \\
\hline Social welfare & $\begin{array}{l}\text { - Increase of participation of citizens; } \\
\text { - Increasing the quality and number of services; } \\
\text { - E-government not only includes services provided electronically, but also } \\
\text { offers tools for citizen-state interaction (Markellos et al., 2014) }\end{array}$ \\
\hline
\end{tabular}

Source: Compiled by the authors.

Some of the problems of e-governance are that the digital services (Tangi et al., 2020) sometimes have security problems that violate citizens' privacy (Erkut, 2020). Furthermore, many citizens are not familiar with the use of new technology.

\section{The Greek public administration}

Public administration personifies the expression of the volition of the implemented government policy (Denhardt et al., 2013) and emerges in various forms (Pownal, 2013). The public administration developed in parallel with the establishment of the state deals with the management and implementation of government policies and programs as well as with the organization and management of the human resources served (Keller, 2007).

Public administration human resources are made up of the public administrators and officers who face three fundamental challenges to governance (Carpenter, 2011). Its mission is the successful implementation of the public mission, the support of the implemented policy (Deligaouri, 2013) and the treatment of the failures. The management of human, material and intangible resources for the implementation of public policy (Moreno-Enguix et al., 2018) is the purpose of the so-called public management (Gray and Jenkins, 2006).

Public administration is oriented to serve the public interest that arises from the needs of society as a whole (Marshall, 2018). The Greek public administration is based on the rules of public law, and is distinguished from the other two state functions, the legislative and the judicial, called the executive function (Greek legislation, 2019). In addition, the Greek public administration, in parallel with the elected government, is able to issue regulatory acts based on the relevant powers of the current legislation, setting rules of public law. The Greek public adminis- 
tration is obliged by the Greek constitution to the impartial execution of its duties arising from the implementation of the decisions of the elected government, to which it belongs hierarchically.

The Greek public administration was established with the advent of the third term of the Hellenic Republic, the establishment of the new political system of the presiding parliamentary democracy and the Constitution of 1975. It includes ministries, local governments, public legal entities and autonomous authorities. The purpose of the Greek public administration is focused on the implementation of the policy of the elected government, the management of failures from the implemented public policy as well as the organizational management of human and material resources and managing public governance failures (Gunawong and Gao, 2017).

\subsection{Structure of the Greek public administration}

The Greek public administration includes the general government, the Legal Entities under Public Law (L.E.P.L.) and the Public Enterprises and Organizations (P.E.O.) (Greek legislation, 2017). General government is structured in central government, social security and local government organizations, while the legal entities under public law in public hospitals, universities and a number of other public bodies within the scope of public administration and finally public enterprises and organizations include those companies that still belong to the Greek State or are controlled by a percentage.

Figure 1 outlines the structure of the Greek public administration as reflected in the current Greek legal code (Greek legislation, 2017). Public administration includes general government (G.G.), legal entities under public law (L.E.P.L.) and public enterprises and organizations (P.E.O.). The key points to pay attention to are initially the separation of general government into central government, local government and social insurance, and then the separation of central government into central administration, public organizations and autonomous authorities. The central government controls the ministries, the decentralized administrations, the autonomous organizations, and the presidency of the Republic and the Parliament.

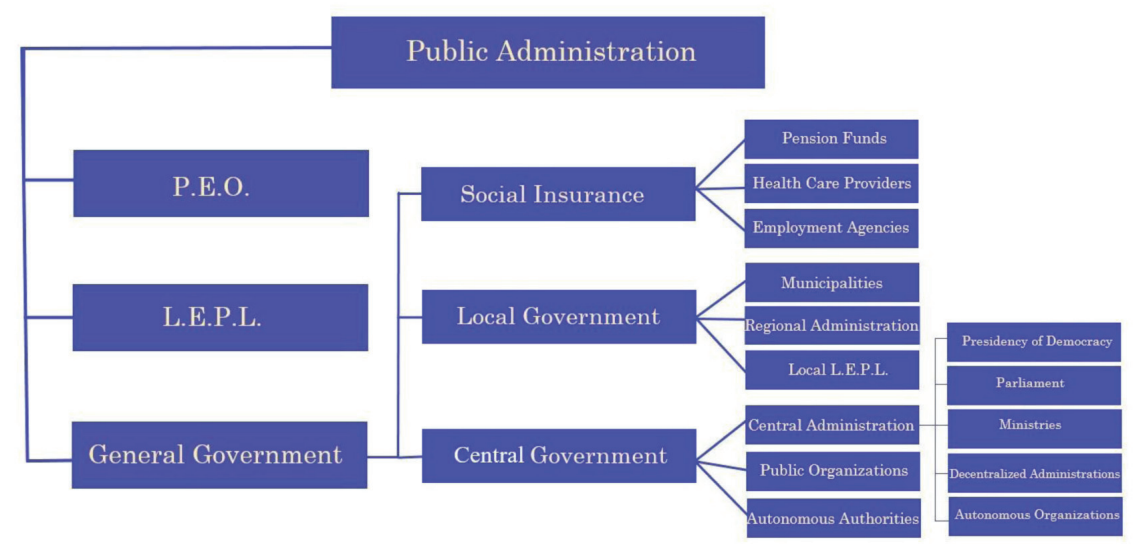

Figure1: Structure of the Greek public administration 
As follows from the above diagram, the distinction of the Greek public administration aims for the central government in the traditional restrictive character of the state having the role of observing the current legislation, with the L.E.P.L. in the provision of services of social value such as health, education or social welfare as well as with P.E.O. in the provision of products and services to serve the public interest. As far as the applied management system is concerned, it is characterized as centralized for the responsibilities of public bodies to exercise regulatory decisions throughout the Greek territory, decentralized in terms of the decisions taken for their legally decentralized administrations whose executives are appointed by the central government, as well as in self-governing for the responsibilities of the region-elected municipalities and peripheries. From a legal point of view, based on the Greek constitution, the Greek territory is organized based on the decentralized system of public administration (McCue and Pitzer, 2000).

The Greek public administration is distinguished for its bureaucratic style based on Napoleonic administrative tradition (Featherstone, 2015) as well as the slowness that can lead in some cases to inefficiency and e-insufficiency (Choi and Park, 2018). The need to transform the traditional model of governance of the Greek public administration as well as the driving forces that have put pressure on the bureaucracy (Philippidou, 2005), such as the gradual liberalization of markets, globalization and information technology in the last two decades, has provoked several announcements and attempts aimed at Greek reform.

Despite the announcements and the countless laws that were passed for the modernization of the public administration in the context of the treatment of the Greek public government debt (Ghourchian and Yilmazkuday, 2020) that correspond to the memoranda of cooperation with the European creditors, the operation of the Greek public administration has not led to the offer of significant differentiations. However, in terms of structure, it should be noted that in recent decades a new model of public administration has emerged for the Greek operating standards, namely autonomous authorities or organizations that either have a separate legal form from the central administration or operate as so-called autonomous organizations (Jeannot et al., 2018).

The obsession with the autonomous authorities in recent years raises questions as to whether it managed to escape from the traditional culture of Greek public administration, namely the classic state-owned government model of the traditional Greek political partisanship line up (Allan and Scruggs, 2004). However, it certainly communicatively provided the Greek citizens with the feeling that the public administration can perform without the emancipated guidance from the politically elected government.

\subsection{Organizational behavior of the Greek public administration}

The operation of the public sector is defined by laws, presidential decrees and ministerial decisions and are analyzed in circular instructions of the public administration. Each public service operates on the basis of a legislative decree that defines the operating framework of each service and that constitutes the Organization of the service. The framework of each organization includes the organic positions of the public service containing the responsibilities and the job descrip- 
tion, the structure of the organizational function, the objectives of the service, the available e-services as well as the existing hierarchy of administration and the way it is staffed, and the digital-ready legislation (Plesner and Justesen, 2021). The basic legislative decree of the operation of the public administration is the socalled Civil Service Code (Greek legislation, 2007) which contains the framework of recruitment, operation and behavior as well as the disciplinary and criminal responsibility of the human resources of the Greek state.

From an organizational point of view, the model of administration of the Greek state is quite bureaucratic, with emphasis on the hierarchy and the penalties for violating the legal requirements, while there is no essential reference to the motivation of human resources (Varotsis, 2019). In addition, the organizational behavior of employees is covered only by some individual codes of ethics and the behavior of human resources, which insist more on the presentation of penalties for its violation than in self-improvement and training. It is possible that the implementation, performance and adoption of e-government implementation will be significantly affected by organizational and political actors (Coursey and Norris, 2008).

The organizational behavior of the public administration is a key factor of an effective public management that aims to improve the services provided (Grimmelikhuijsen et al., 2016) and to modernize the operation through the implementation of e-government (Introna et al., 2010). The organizational behavior of public administration is something broader than human relationships of public servants' at work and the key to success in implementing an innovation in an organization. In public administration, the effective management of the organizational behavior of public organizations has a positive correlation with the improvement of productivity and a high degree of job satisfaction as well as the development of an organizational culture that leads to the interest and service of the citizen (Wirtz and Kurtz, 2016).

The implementation of e-government changes the behavior of human resources of public administration and can be a means of motivating not only to the improvement of the functionality of the project but also to the citizens' participation (Dimitrova et al., 2006). Certainly the reestablishment of e-government is the application of a collaborative innovation in public administration (Torfing, 2019) and furthermore a challenge to address an organizational change that aims to improve both human relations of human resources and the improvement of services provided.

\subsection{The role of internal auditing in the improvement of e-governance}

According to the Institute of Internal Auditors (I.I.A., 2020) an internal audit is "an independent, objective assurance and consulting activity designed to add value and improve an organization's operations. It helps an organization accomplish its objectives by bringing a systematic, disciplined approach to evaluate and improve the effectiveness of risk management, control, and governance processes". The above definition shows that the main goal of internal control is to improve the governance of an organization or a company (Tumwebaze et al., 2018).

Internal control is crucial to improving corporate processes and management (Kontogeorgis, 2018). The operation of internal auditing in the public sector in Greece is a reality as the operation has been strengthened from 1999 until today through the legislation provisions concerning internal audits (Kontogeorgis and Filos, 2012). 
Internal auditing can measure if the principles of governance are applied and how effective and efficient is the operation of the public sector (Asare, 2009). Internal auditors need to be well acquainted with corporate processes because they evaluate them in order to make them more effective (Moeller, 2009). The internal audit can check whether the Greek public administration applies the principles of e-government or not. Monitoring the implementation of the principles of e-government is valuable in order to identify weaknesses and make necessary improvement changes.

\subsection{Transparency of the Greek public administration}

Transparency is a measure of the perception of acceptable information by a transmitter (Varotsis and Katerelos, 2018). Enhancing the access, understanding and accuracy of information by any means to stakeholders increases the level of transparency (Bertot et al., 2010). At the political level, management of government information omits barriers to access that affect public decision-making.

Transparency in public administration is inherent in the integrity and ethics of political leaders and government officials, as well as in the accountability of civil servants and the extent to which anti-corruption policies are implemented (Alt and Lassen, 2006). A government that publishes all managed information excluding sensitive information that threatens national security (Hartmann and Steup, 2015) or privacy (Greek legislation, 1997) - effectively enhances transparency (Gunawong, 2015).

Greek governments have periodically made significant efforts to increase transparency and public access to available government information, such as the establishment of e-governance as well as the implementation of the so called "diavgeia", a website that obliges with a relevant legal framework of the entire public administration publishing every decision related to the operation of public administration, its regulatory decisions, announcements and declarations as well as anything related to expenses and budgets enhancing government transparency (Bonson et al., 2012).

The establishment of independent authorities as well as autonomous public bodies emphasizing the establishment of the so-called "asep" - which means supreme council for civil personnel selection - the independent body that manages the public announcements for recruitment of the permanent staff of the public sector, aimed at the strengthening of government transparency. On the other hand was the creation of a series of named independent authorities over the last two decades aimed at increasing transparency and accountability (Halachmi and Greiling, 2013), without necessarily being confirmed over time by credible reports. In recent decades, however, policies have been implemented to enhance government transparency, which strengthens public confidence in public administration (Spanou and Sotiropoulos, 2011).

\section{The evolution of digital governance in Greece}

For many years there was no specific legislation regarding e-government in Greece and the relevant provisions were derived from general administrative principles and laws (Iglezakis, 2008). Law 4727/2020 is considered a milestone law in digital governance in our country. The reason is that it includes innovative pro- 
visions concerning digital governance and is aimed at improving it. Some of the innovative provisions of law 4727/2020 are:

- Issuance of personal number to citizens: The main goal is for this number to be the only number that citizens will have. In particular, the abolition of the V.A.T. (Value Added Tax) number and A.M.K.A. (Social Security Registration Number) number is foreseen in the next ten years.

- The online registered delivery service is introduced. This service aims to replace traditional delivery of documents with e-mail.

- The Institutionalization of rules of the Public Procedures. The main goal is for citizens to know the procedures required in order to complete a transaction from the state service. This will help reduce downtime and corruption in the public sector.

- Digital governance awards are institutionalized for high performance organic units.

- Arrangements for the installation of communication systems $5 \mathrm{G}$ are arranged.

- It is planned to abolish the use of fax as a means of communication from 1/1/2021 (Greek Legislation, 2020).

- Enhance the services provided by the gov.gr website.

- Public services must communicate with citizens online and have a website.

Beyond the above law, efforts have been made to implement e-government in Greece, however, without great results. The most important attempts to implement e-government in the Greek public administration are presented in the table below:

Table 3

\section{Attempts to implement e-government in the Greek public administration}

\begin{tabular}{|c|c|}
\hline Programs /laws & Description \\
\hline Taxisnet & $\begin{array}{l}\text { It operated in } 2000 \text { and from year to year improved its services. It offered } \\
\text { innovative services such as electronic submission of income tax return, } \\
\text { VAT return, certificate of non-debt to the state }\end{array}$ \\
\hline Syzefxis & $\begin{array}{l}\text { Launched in } 2001 \text { as a pilot application for } 15 \text { public bodies. It is the national } \\
\text { local network for public sector services. Discussions on its upgrade have been } \\
\text { ongoing for many years }\end{array}$ \\
\hline Ika web site & Employers have the option of filing employee contributions electronically \\
\hline $\begin{array}{l}\text { Citizen Service } \\
\text { Centres - KEP }\end{array}$ & $\begin{array}{l}\text { The initial submission of the website http://www.kep.gov.gr. was to provide } \\
\text { information on some of the state's key transactions with citizens and } \\
\text { businesses. The aim was for citizens to visit a part of the state in order to settle } \\
\text { time-consuming bureaucratic procedures (Iglezakis, 2008) }\end{array}$ \\
\hline $\begin{array}{l}\text { Information } \\
\text { Society S.A. }\end{array}$ & $\begin{array}{l}\text { It is a Greek public company and was founded in } 2001 \text { with the aim } \\
\text { of accelerating the adoption of e-government applications in Greece }\end{array}$ \\
\hline $\begin{array}{l}\text { General Secretariat } \\
\text { for Public } \\
\text { Administration } \\
\text { and E-government }\end{array}$ & $\begin{array}{l}\text { It was established in } 2006 \text { with the aim of improving public administration } \\
\text { and the provision of electronic services to citizens }\end{array}$ \\
\hline E-Procurement & $\begin{array}{l}\text { The main objectives of the electronic procurement system were the } \\
\text { simplification and the speed of processing. The establishment of the electronic } \\
\text { procurement system was done with Presidential Decrees 59/2007 and 60/2007 } \\
\text { (Iglezakis, 2008) }\end{array}$ \\
\hline
\end{tabular}




\begin{tabular}{|c|c|}
\hline Programs /laws & Description \\
\hline $\begin{array}{l}\text { The implementation } \\
\text { of Diaugeia }\end{array}$ & $\begin{array}{l}\text { Law } 3861 / 2010 \text { is known as law "Diaugeia" and provides that public bodies } \\
\text { that issue laws, presidential decrees, and acts must post them publicly on the } \\
\text { Internet. It contributed significantly to transparency in the public sector } \\
\text { (Tsakanikas, Danchev, Giotopoulos, Korra, and Pavlou, 2014) }\end{array}$ \\
\hline $\begin{array}{l}\text { Ministry of Digital } \\
\text { Governance }\end{array}$ & $\begin{array}{l}\text { The establishment of the Ministry of Digital Governance - by the Presidential } \\
\text { Decree } 81 / 8-7-2019 \text { - was a very important step towards strengthening } \\
\text { digital governance. The main goals of the Ministry of Digital Government are } \\
\text { the increase of electronic services to citizens and the digital transformation } \\
\text { of Greece (Mission/Ministry of Digital Governance, 2020) }\end{array}$ \\
\hline $\begin{array}{l}\text { The operation of the } \\
\text { website gov.gr }\end{array}$ & $\begin{array}{l}\text { The operation of gov.gr helped a lot in the dissemination of electronic services } \\
\text { (Panayiotou and Stavrou, 2019). The website was launched in March } 2020 \text {. } \\
\text { The operation of the gov.gr website is a very good initiative making citizens } \\
\text { aware of the services offered electronically. The operation of the above } \\
\text { website was combined with innovative services such as e-authorization } \\
\text { and e-declaration. New services are constantly being added that reduce the } \\
\text { bureaucratic burden and increase the service of the citizens }\end{array}$ \\
\hline Law $4727 / 2020$ & It contains many provisions for digital governance \\
\hline
\end{tabular}

Source: Compiled by the authors.

\section{The ranking of Greece in the field of digital governance}

For many years, the Greek public administration has been far from the average model of functioning of the European Union states, as a result of chronic pathogens. On the other hand, it is important to emphasize that this discrepancy is decreasing in relation to the first years of the Greek state's accession to the European Economic Community and the implementation of countless restructuring programs of the Greek public sector (Hahamis et al, 2005), especially in the last decade with fiscal adjustment significantly improving the functioning of public administration.

However, even this improvement is not understood by the average citizen as the years go by, as the requirements for the level and variety of public service provision have been spectacularly increased (Gasova and Stofkova, 2017). Moreover, the comparison of the Greek economy and the operation of the state with the corresponding European states constantly leaves complaints while ignoring that the national culture of Greek society differs significantly compared to the corresponding one in most countries of the European Union (Linan et al, 2014). After all, culture as well as society are by nature dynamic and Greek society is changing and resembling a digital culture even more (Patelis, 2020) while the function of the economy, public administration and institutions respectively follows.

The deviations in the operation of e-government are not far from the total deviation of the supply of public services provided in Greece from the European average. However, before hastily drawing wrong conclusions, it is necessary to pay attention to the large divergence of technological infrastructure in Greece in relation to the most advanced European countries (Mavroudeas et al., 2010) as well as to the available technological means of the Greek public administration which, apart from being meager, seem essentially insufficient to meet modern requirements and avoid bureaucracy (Cordella and Tempini, 2015). 
The European Commission (European Commission, 2020) publishes an annual guide to European governments' benchmarking, measuring through the egovernment index, which incorporates per country the development of digital government (Dias, 2020), e-usability sensitivity, transparency and cross-border mobility. As can be seen from the following diagrams (2, 3 and 4), e-government in Greece is developing yet still lags behind the European average, while the Greek public administration achieves satisfactory convergence in relation to the provision of electronic cross-border services.

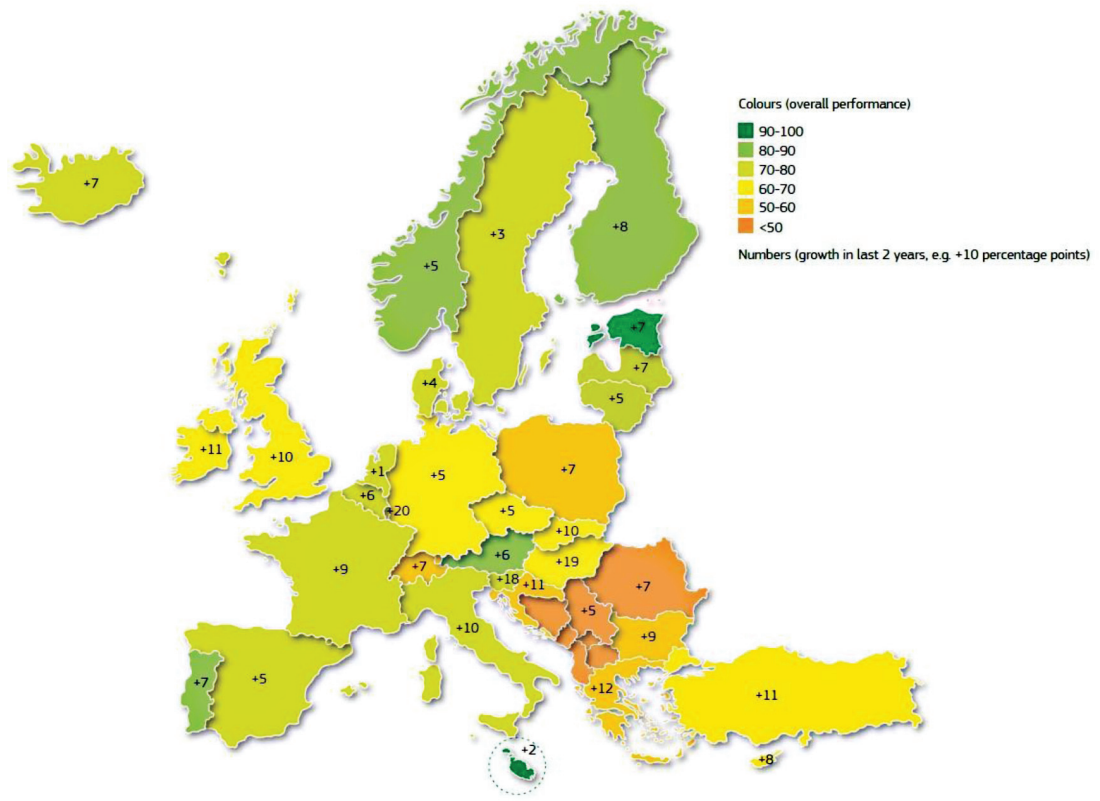

Figure 2. Overall digital delivery of public services performance by country Source: European Commission (2020).

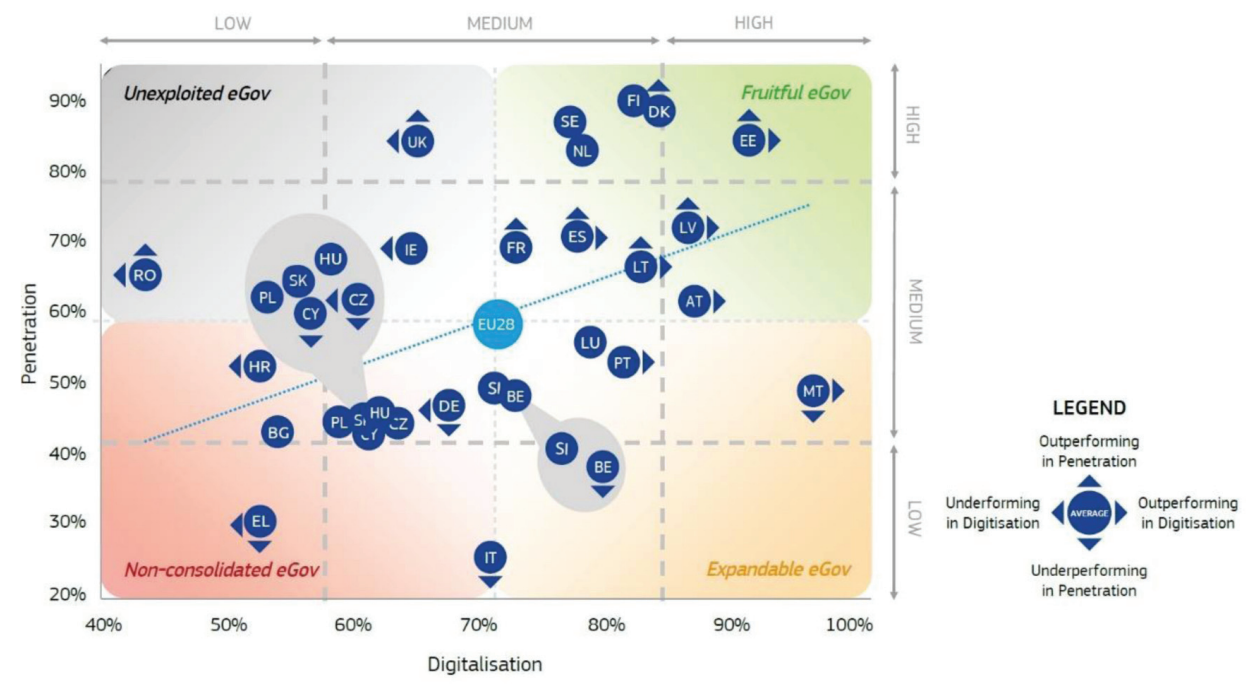

Figure 3. Overall absolute performance in penetration and digitization by country

Source: European Commission (2020). 
Despite the fruitful steps that have been taken in Greece in the last decade in implementing e-government, plus the avoidance of bureaucracy and e-certification of users, it still lags behind the European average (Androniceanu, Kinnunen and Georgescu, 2020). Greece is one of the countries that shows a relative performance below the European trend, with non-optimal results in both penetration and digitization while improving national service delivery, showing a bigger gap between national and cross-border $-84 \%$ and $42 \%$ respectively. In concrete areas the benchmarking shows that the Greek public administration is still relatively sophisticated (e.g. citizen service centers), however, still lags behind in terms of transparency as well as the diffusion of government services into the overall operation of the Greek economy.

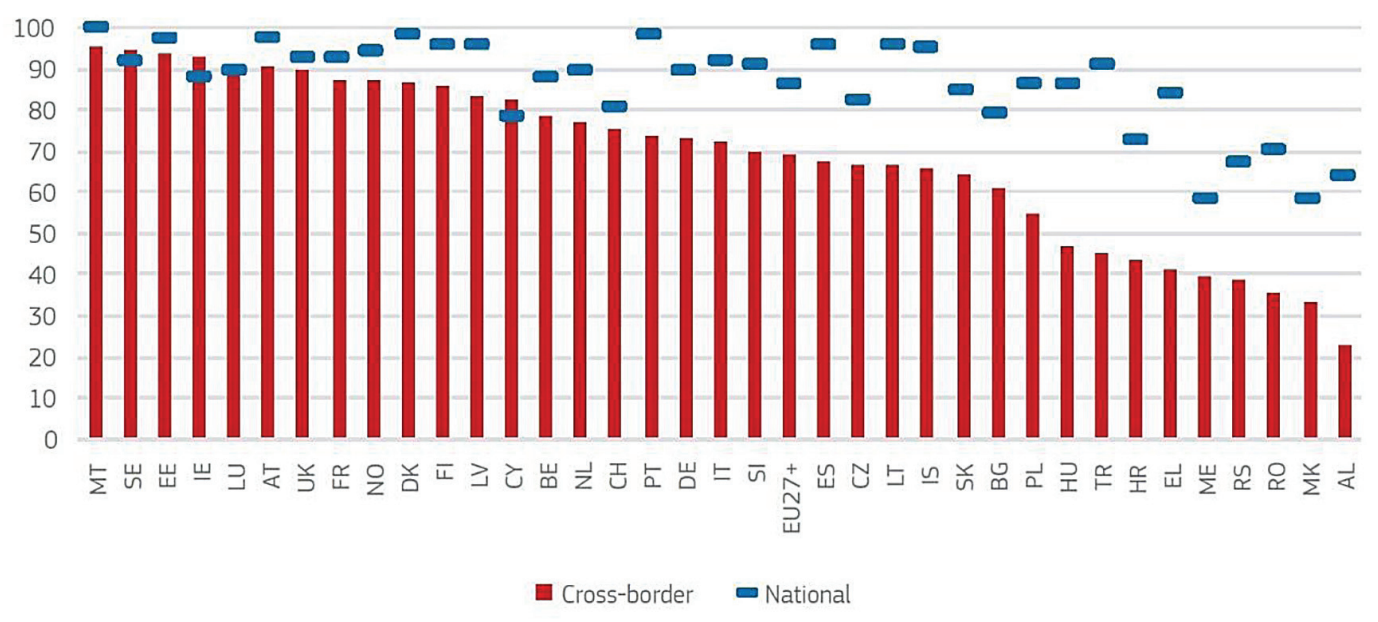

Figure 4. Digital availability for national and cross-border services

Source: European Commission (2020).

According to the benchmarking approach analysis (European Commission, 2020), through the Digital Economy and Society Index (DESI) integrating digital public services, integration of digital technology (Delgosha et al, 2020), use of internet services, human capital and connectivity, Greece ranks among the states with the lowest score in the European Union. It is characteristic that it occupies one of the lowest positions in the use of digital public services due to the absence of user-friendly applications. The Greek digital e-government (Bortic and Bozic, 2021) in comparison with the leading European countries in the government digitization of services such as Finland and Estonia, differs in that in these countries the public services (Inkinen, 2012) are provided exclusively digitally through mobile e-government options (Björklund, 2006).

The physical presence of Greek citizens in public services is related not only to the lack of provision of digital public software by the Greek public administration but also partly to a differentiated information seeking behavior (Wilson, 1999; Taylor, 2018). As a result, despite the steps that have been taken in recent years to digitize public services - something that was partially accelerated 
by the new conditions that emerged from the epidemiological data of covid-19the process in which of the Greek citizen is forced to visit on public websites is related to a remnant of anachronistic human culture (Floyd, 2014).

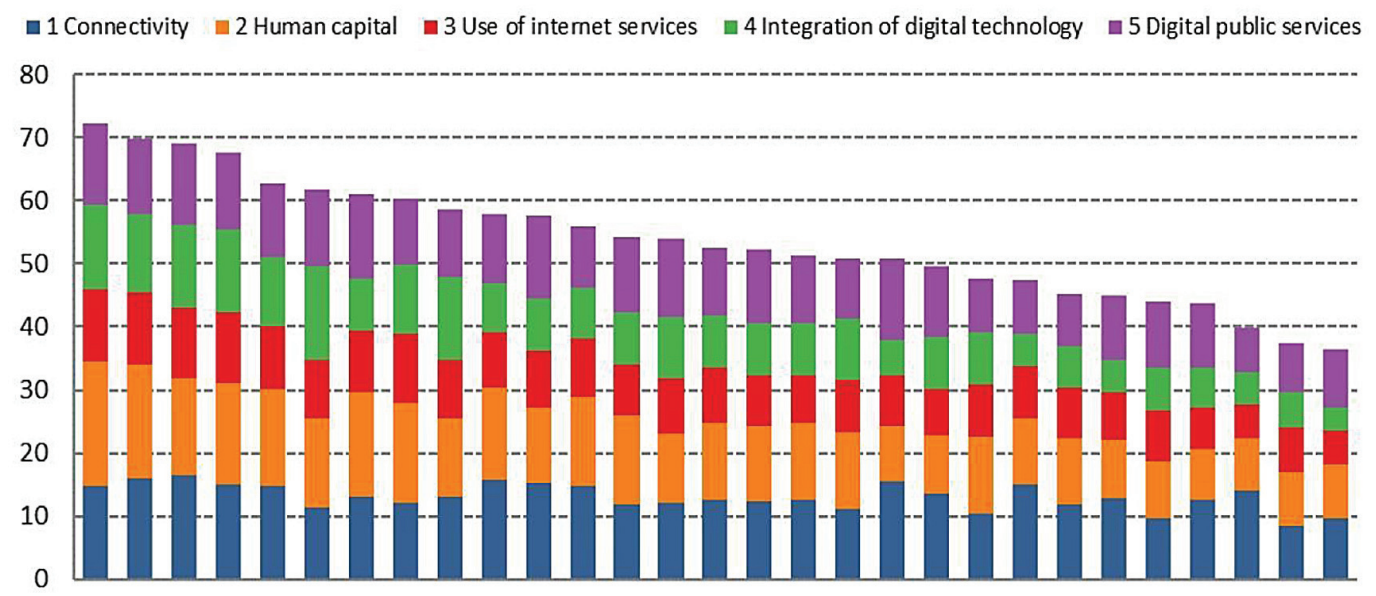

FI SE DK NL MT IE EE UK BE LU ES DE AT LT EU FR SI CZ LV PT HR HU SK PL CY IT RO EL BG

Figure 5. Digital Economy and Society Index, 2020.

Source: European Commission (2020).

The modernization of the e-government of the Greek public administration in each case is related to political decisions such as the political will to implement strategic plans for the digitization of public services, careful and gradual adoption of "New Public Administration" standards (Pyun and Gamassou, 2017), simplification of legislation (Spinellis et al., 2018) or/and a revised fiscal and tax policy (Varotsis and Katerelos, 2020). However, the efforts of the last two decades have shown that in addition to implementing and investing in new technological and digital applications, it is necessary to be accompanied by a public sector reform (Katsonis and Botros, 2015) of information behavior and human culture of the public as well as a digital development model (Cruz-Jesus et al., 2016).

\section{Methodology}

The aim of this research is to verify the hypothesis regarding the backwardness of the evolution of digital governance in Greece. More specifically, it is to identify the dimensions in which e-governance lags behind in Greece in relation to other advanced intergovernmental digital systems, in order to be a basis for a re-establishment of its policies. The method adopted to verify this hypothesis is benchmarking with indicators representing various aspects and dimensions of e-governance or governance involvement, based on reliable, internationally comparable data. The verification is based on the comparability between pairs of indicator measurements that represent the indicators-dimensions of e-government. 
The research data come from two internationally recognized benchmark instruments: the E-Government Survey 2020 by the United Nations (UN), and the Digital Government Index 2019 by the Organization for Economic Co-operation and Development (OECD). The latest versions were used - 2020 for the $\mathrm{UN}$ and 2019 for the OECD - from these instruments. The data therefore covers all 193 countries of the United Nations, strengthening the comparison in the 31 countries of OECD instruments - 29 OECD member countries and 4 nonmember countries.

The selection of indicators among these instruments was made taking into account the internationally recognized criteria that cover all dimensions both in terms of services and in terms of technological infrastructure, while in addition they have a defined coverage and are independent of each other. Table 4 and Table 5 below show the interpretation of each of the selected comparability indicators of e-governance.

Table 4

Interpretation of OECD benchmarking indicators-dimensions

\begin{tabular}{|l|l|}
\hline \multicolumn{1}{|c|}{ Criteria } & \multicolumn{1}{|c|}{ Description } \\
\hline Digital by design & $\begin{array}{l}\text { This dimension examines the extent to which the government has } \\
\text { introduced new technologies for the organizational restructuring } \\
\text { of public services. The introduction of digital tools aims to ensure } \\
\text { the supervision, implementation and design of the services offered. }\end{array}$ \\
\hline Data Driven Public Sector & $\begin{array}{l}\text { This dimension examines whether the data collected is used } \\
\text { to better design services and policies. In addition, the degree } \\
\text { of protection of information, confidentiality and privacy } \\
\text { is examined. }\end{array}$ \\
\hline Government as a platform & $\begin{array}{l}\text { This dimension examines the extent to which government } \\
\text { information and services are offered in a unified and interoperable } \\
\text { manner. }\end{array}$ \\
\hline Open by default & $\begin{array}{l}\text { This dimension examines the level and amount of information } \\
\text { provided by the government. The provision of public information } \\
\text { should be in accordance with the law. }\end{array}$ \\
\hline User driven & $\begin{array}{l}\text { This dimension examines the extent to which governance focuses } \\
\text { on users - citizens. In particular, it examines the extent to which } \\
\text { users' needs are taken into account in the design of processes, } \\
\text { services and policies. }\end{array}$ \\
\hline Proactiveness & $\begin{array}{l}\text { This dimension examines the extent to which the services provided } \\
\text { by the state meet the needs of the citizens. The success of this } \\
\text { dimension depends on the application of the above five dimensions }\end{array}$ \\
\hline Then
\end{tabular}

Source: OECD, 2019.

The selection of instruments is based on the credibility of the OECD and $\mathrm{UN}$ in the benchmarking surveys of e-government. The selection of benchmarking with country e-government measurements for Germany is as the largest economy due to GNP of the European Union while for Portugal, Sweden and Israel it is due to their population compatibility with Greece. 
Table 5

\section{Interpretation of UN benchmarking indicators-dimensions}

\begin{tabular}{|l|l|}
\hline \multicolumn{1}{|c|}{ Criteria } & \multicolumn{1}{c|}{ Description } \\
$\begin{array}{l}\text { The Online } \\
\text { Services Index }\end{array}$ & $\begin{array}{l}\text { Results of questionnaire estimating the spread of the internet in the UN Member } \\
\text { States. The questionnaire consists of } 148 \text { questions. Factors such as the quality } \\
\text { of government websites, the provision of electronic services, and the electronic } \\
\text { participation of citizens are measured }\end{array}$ \\
\hline $\begin{array}{l}\text { Telecom- } \\
\text { munications } \\
\text { Infrastructure } \\
\text { Index }\end{array}$ & $\begin{array}{l}\text { It is a numerical index consisting of four sub criteria. 1. number of users per } \\
100 \text { inhabitants 2. number of mobile phone subscriptions per } 100 \text { inhabitants } \\
\text { 3. active mobile-broadband subscription 4. number of fixed broadband } \\
\text { subscriptions per 100 inhabitants }\end{array}$ \\
\hline $\begin{array}{l}\text { Human Capacity } \\
\text { Index }\end{array}$ & $\begin{array}{l}\text { It is a numerical index consisting of four sub criteria: } \\
\text { 1. adult literacy rate; } \\
\text { 2. the combined primary, secondary and tertiary gross enrolment ratio; } \\
\text { 3. expected years of schooling; and } \\
\text { 4. average years of schooling }\end{array}$ \\
\hline
\end{tabular}

Source: UN, 2020.

\section{Findings}

The results of all the selected benchmarking indicators of e-governance are shown in Table 6.

Table 6

\section{Benchmarking indicators}

\begin{tabular}{|c|c|c|c|c|c|c|c|c|}
\hline $\begin{array}{l}\text { OECD } \\
\text { Criteria }\end{array}$ & $\begin{array}{c}\text { UN } \\
\text { Criteria }\end{array}$ & Greece & Sweden & Portugal & Germany & Israel & $\begin{array}{l}\text { OECD } \\
\text { Average }\end{array}$ & $\begin{array}{c}\text { UN } \\
\text { Average } \\
\text { World }\end{array}$ \\
\hline $\begin{array}{l}\text { Dimension 1: } \\
\text { Digital } \\
\text { by design }\end{array}$ & & 0.30 & 0.28 & 0.63 & 0.50 & 0.60 & 0.55 & \\
\hline $\begin{array}{l}\text { Dimension 2: } \\
\text { Data Driven } \\
\text { Public Sector }\end{array}$ & & 0.35 & 0.35 & 0.50 & 0.27 & 0.49 & 0.44 & \\
\hline $\begin{array}{l}\text { Dimension 3: } \\
\text { Government } \\
\text { as a platform }\end{array}$ & & 0.39 & 0.33 & 0.85 & 0.37 & 0.77 & 0.54 & \\
\hline $\begin{array}{l}\text { Dimension } 4: \\
\text { Open by default }\end{array}$ & & 0.69 & 0.36 & 0.55 & 0.55 & 0.68 & 0.64 & \\
\hline $\begin{array}{l}\text { Dimension 5: } \\
\text { User driven }\end{array}$ & & 0.21 & 0.10 & 0.43 & 0.31 & 0.50 & 0.47 & \\
\hline $\begin{array}{l}\text { Dimension 6: } \\
\text { Proactiveness }\end{array}$ & & 0.13 & 0.11 & 0.52 & 0.41 & 0.58 & 0.42 & \\
\hline $\begin{array}{l}\text { Composite } \\
\text { Results }\end{array}$ & & 0.35 & 0,26 & 0.58 & 0.40 & 0.60 & 0.50 & \\
\hline
\end{tabular}




\begin{tabular}{|c|c|c|c|c|c|c|c|c|}
\hline \multirow[t]{5}{*}{$\begin{array}{c}\text { OECD } \\
\text { Criteria }\end{array}$} & $\begin{array}{c}\text { UN } \\
\text { Criteria }\end{array}$ & Greece & Sweden & Portugal & Germany & Israel & $\begin{array}{c}\text { OECD } \\
\text { Average }\end{array}$ & $\begin{array}{c}\text { UN } \\
\text { Average } \\
\text { World }\end{array}$ \\
\hline & $\begin{array}{l}\text { The Online } \\
\text { Services } \\
\text { Index }\end{array}$ & 0.7059 & 0.9 & 0.8353 & 0.7353 & 0.7471 & & 0.562 \\
\hline & $\begin{array}{l}\text { Telecom- } \\
\text { munications } \\
\text { Infrastructure } \\
\text { Index }\end{array}$ & 0.81 & 0.9625 & 0.7948 & 0.8856 & 0.8689 & & 0.5464 \\
\hline & $\begin{array}{l}\text { Human } \\
\text { Capacity } \\
\text { Index }\end{array}$ & 0.8905 & 0.9471 & 0.8463 & 0.9362 & 0.8924 & & 0.688 \\
\hline & $\begin{array}{l}\text { Normalized } \\
\text { Composite } \\
\text { Index }\end{array}$ & 0.8021 & 0.9365 & 0.8255 & 0.8905 & 0.8361 & & 0.5988 \\
\hline
\end{tabular}

Source: OECD, 2020; UN, 2020.

The first comparison made regarding the level of e-government is the performance based on the OECD criteria. Based on the composite results of the comparative analysis, we observe that the composite performance of Greece is below the average for OECD countries. Specifically, the performance of Greece is 0.35 , while the average for OECD countries is 0.50. Greece's great weaknesses seem to be in Dimension 5 and Dimension 6. Specifically, Greece's performance in the criterion User Driven is 0.13 , (while the average for OECD countries is 0.47 ) and Greece's performance in the criterion Proactiveness is 0.13 (while the average for OECD countries is 0.42 ). Greece lags significantly behind in the criterion Digital by design ( 0.30 versus 0.55 of the OECD average). Greece performs lower than most OECD countries including Portugal, Germany and Israel. Greece has a better performance than Sweden (0.35 versus 0.26$)$.

The second comparison made regarding the level of e-government is the performance based on the United Nations (UN) criteria. Based on the normalized composite results of the comparative analysis, we observe that the composite performance of Greece is above the average of the UN countries. Specifically, the performance of Greece is 0.8021 , while the average for UN countries is 0.5988. Greece performs lower than Portugal, Germany, Sweden and Israel. A particularly important finding is that Sweden has a very high performance compared to its performance in the OECD criteria. This fact shows the complexity of the criteria and it is vital to take into account various criteria in order to examine the level of e-governance.

\section{Conclusion and future directions}

The main purpose of digital governance is to provide value-added services for citizens (Criado and Gil-Garcia, 2019). Some reasons for improving digital governance are (Tsakanikas et al., 2014) the reduction of the public sector's 
operating costs, the increase in the competitiveness of Greece as an investment destination, the improvement of transparency as well as the improvement of employment. These can take place with the adoption of digital signatures in the public sector, the increase of open information and the adjustment to services requested by the citizen (Venkatesh et al., 2012).

The lack of a complete information system that can provide a wide range of digital services (Schneider et al., 2020), such as lack of digital applications, low network e-government accessibility, insufficient training (Heeks and Stanforth, 2007), lack of interactivity with the public, security risks, inaccessibility of e-government websites by the entire population, and internet costs (Batalli, 2011) increase the comparative disadvantage as time goes on. Weaknesses of the existing information system in matters of identification, digitalization and security of the users of the e-government services perpetuate the lack of modern e-government applications provided (Brown and Toze, 2017). A government policy aimed at ease of use, utility and privacy that are key factors in accepting the e-government portal can be the key to re-establishing e-government. (Wirtz et al., 2015).

Benchmarking of e-government performance shows the shortcomings in egovernment policies in Greece. Greece is significantly behind in terms of criteria digital by design, user driven and proactiveness according to the findings of the comparative evaluation of the OECD. Greece should implement policies that enhance its performance in the specific criteria - dimensions of the OECD. The need has also arisen to introduce more sophisticated tools to ensure the design, implementation and oversight of services provided by the state. It may be necessary to record the needs of citizens for services provided in order to ensure an adjustable design of public services (Trischler et al., 2019). Finally, recording the needs of citizens should be a key tool for additional requested electronic provided services (Malodia et al., 2021). The gratification of citizens' needs is a key parameter that will improve Greece's performance in the criteria of digital by design, user driven and proactiveness.

Another key tool for comparing e-government in Greece with other countries is the UN criteria. The findings of the comparison show that Greece has a significantly better performance compared to the average of the countries of the United Nations. Nevertheless, Greece is performing worse than Sweden, Portugal, Germany and Israel. Various policies can be implemented to improve Greek e-government performance in the UN e-government criteria.

Findings based on possible research regarding the quality and quantity of electronic services can make relevant improvements and enrichment of services. In addition, incentives can be provided for the use of the internet such as generous subsidies taking advantage of European financial instruments. A readjustment of education focused on informatics can improve the public's use of digital services ( $\mathrm{Hu}$ et al., 2020). Other policies that can be implemented in order to improve the e-government are the modernization of Greek legislation with technology, provision of open access information in an easy way, ensure use of the Internet for all citizens, reduction of illiteracy, the application of new technologies, ensure the participation of the public in the design and 
implementation of electronic services, ensure the ability to manage IT services, and simplification of the use of electronic services (World Bank, 2016).

Taking into account the criterion of the country's population territory (Kuhlmann and Jakel, 2013), the benchmarking of the e-governance of Greece can be compared with the e-governance of other countries with a corresponding population in Europe (e.g. Belgium, Czech Republic, Hungary) or in the rest of the world (e.g. Tunisia, United Arab Emirates). The benchmarking could be extended to other countries based on Greece's geographical location by comparing it to the e-governance of neighboring countries such as Bulgaria, Turkey, Romania, Italy and Egypt. In addition, based on the Telecommunications Infrastructure Index of the UN, the comparative evaluation of the Greek e-governance could be carried out in relation to the e-governance of Ireland, Poland and Latvia while, based on the Online Services Index, the comparative evaluation can be extended in relation to the respective e-governances of Paraguay, Azerbaijan and Belarus.

The administrative and work culture differs (Heusala and Koistinen, 2018) on public servants of state governments from state to state. In addition, the culture of the peoples of the states also differs. Population culture influences information seeking behavior (Somera et al., 2016) with the consequent need for additional adjustments in e-governance. Therefore, a further study with similar or broader objectives will include both the administrative and work culture and the informational seeking behavior of the citizens of Greece.

Moreover, the effective usage of Information and Communication Technologies (ICTs) in e-governance (Asongu and Nwachukwu, 2018) can greatly enhance the existing efficiency of work and the quality of e-services offered as well as enhance the transparency of the overall operation of the government. The relationship between ICTs and effective e-governance can be examined through additional relevant interdisciplinary research in order to explore the technological, political, economic, organizational and social interfaces. Extending the investigation of comparative evaluation of e-governance with similar government and administrative cultures (Van der Wal, 2021) will serve to verify and achieve greater acceptance of the findings of the present research.

The presented literature review and benchmarking of e-government in Greece have several limitations. The research is based on qualitative content analysis and the conclusions are concentrated on the published research data to date, without the possibility of further knowledge of possible underlying policies of the Greek government aimed at improving e-government. In addition, the benchmarking could in the future be extended to further surveys, of the World Economic Forum or the World Bank Group, for instance.

Despite the limitations, the findings trace what future policies should look to for the effective re-establishment of e-government. Further research should focus on the establishment of a plan with strict timetables in the restoration of technological infrastructure, re-examining the needs of citizens for digital services, and carefully examining the impact of e-government (Perez-Morote et al., 2020) on the organizational process for the implementation of e-government in order to understand the implications at team and organization level. 


\section{REFERENCES}

Alexopoulos, C., Loukis, E., Mouzakitis, S., Petychakis, M. and Charalabidis, Y. (2015) 'Analysing the characteristics of open government data: Sources in Greece', J Knowl Econ, (9), pp. 721-753.

Allan, J.P. and Scruggs, L. (2004) 'Political partisanship and welfare state reform in advanced industrial societies', American Journal of Political Science, 48(3), pp. 496-512.

Alt, J.E. and Lassen, D.D. (2006) 'Transparency, political polarization, and political budget cycles in OECD countries', American Journal of Political Science, 50(3), pp. 530-550.

Androniceanu, A., Kinnunen, J. and Georgescu, I. (2020) 'E-Government clusters in the EU based on the Gaussian Mixture Models', Administratie si Management Public, 35, pp. 6-20.

Asongu, S.A. and Nwachukwu, J.C. (2018) 'The role of openness in the effect of ICT on governance', Information Technology for Development, 25(3), pp. 503-531.

Batalli, J.C., Jaeger, P.T. and Grimes, J.M. (2010) 'Impact of public administration innovations on enhancing the citizens' expectations', International journal of e-education, e-business, e-management and e-learning, 1(2), pp. 156-162.

Bertot, M. (2011) 'Using ICTs to create a culture of transparency: E-government and social media as openness and anti-corruption tools for societies' Government Information Quarterly, 27, pp. 264-271.

Björklund, F. (2016) 'E-government and moral citizenship: The case of Estonia', Citizenship Studies, 20(6-7), pp. 914-931.

Bonson, E., Torres, L., Royo, S. and Flores, F. (2012) 'Local e-government 2.0: Social media and corporate transparency in municipalities', Government Information Quarterly, 29 (2), pp. 123-132.

Botric, V. and Bozic, L. (2021) 'The digital divide and e-government in European economies', Economic Research-Ekonomska Istraživanja. DOI: 10.1080 /1331677X.2020.1863828.

Brown, D.C. and Toze, S. (2017) 'Information governance in digitized public administration', Canadian Public Administration, 60(4), pp. 581-604.

Carpenter, D.P. and Krause, G.A. (2011) 'Reputation and public administration', Public administration review, 72(1), pp. 26-32.

Choi, H. and Park, M.J. (2018) 'Excellence for social progress: Focusing on low and lower-middle-income countries', Soc Indic Res, 141, pp. 111-130.

Cordella, A. and Tempini, N. (2015) 'E-government and organizational change: Reappraising the role of ICT and bureaucracy in public service delivery', Government Information Quarterly, 32, pp. 279-286. Available at: https://doi.org/10.1016/j.giq.2015.03.005

Coursey, D. and Norris, D.F. (2008) 'Models of e-government: Are they correct? An empirical assessment', Public Administration Review, 68 (3), pp. 523-536. 
Criado, J.I., and Gil-Garcia, J.R. (2019) 'Creating public value through smart technologies and strategies: From digital services to artificial intelligence and beyond', International Journal of Public Sector Management, 32 (5), pp. 438-450.

Cruz-Jesus, F., Oliveria, T., Bacao, F. and Irani, Z. (2016) 'Assessing the pattern between economic and digital development of countries' Inf Syst Front, 19, pp. 835-854.

Datareportal Digital 2019: Global Digital Overview. Available at: https://datareportal.com/ reports/digital-2019-global-digital-overview (accessed 12 September 2021).

Dawes, S.S. (2008) 'The evolution and continuing challenges of e-governance', Public Administration Review, 68(Suppl.1). Available at: https://doi.org/10.1111/j.1540-6210. 2008.00981.x. (accessed 12 September 2021).

Delgosha, M.S., Saheb, T. and Hajiheydari, N. (2020) 'Modelling the asymmetrical relationships between digitalisation and sustainable competitiveness: A cross-country configurational analysis, Information Systems Frontiers. DOI: https://doi.org/10.1007/s10796020-10029-0.

Deligiaouri, A. (2013). Open governance and e-rulemaking: Online deliberation and policy-making in contemporary Greek politics. Journal of Information Technology and Politics, 10, pp. 104-124.

Denhardt, R.B., Denhardt, J.V. and Blanc, T.A. (2013) Public administration: An action orientation. Boston: Wadsworth.

Dias, G.P. (2020) Global e-government development: Besides the relative wealth of countries, do policies matter? Transforming Government: People, Process and Policy, 14(3), pp. 381-400.

Dimitrova, D.V. and Chen, Y. (2006) 'Profiling the adopters of e-Government information and services: The influence of psychological characteristics, civic mindedness, and information channels', Social Science Computer Review, 24(2), pp. 172-188.

Dunleavy, P., Margetts, H., Bastow, S. and Tinkler, J. (2006) 'New public management is dead - Long live digital-era governance', Journal of Public Administration Research and Theory, 16(3), pp. 467-494. Available at: https://doi.org/10.1093/jopart/mui057.

Erkut, B. (2020) 'From digital government to digital governance: Are we there yet?' Sustainability, 12(3), pp. 1-13. Available at: https://doi.org/10.3390/su12030860.

European Commission (2020) E-Government benchmark 2020. Brussels: European Commission.

European Commission. (2020) Digital Economy and Society Index (DESI) 2020. Brussels: European Commission.

Featherstone, K. (2015) 'External conditionality and the debt crisis: the 'Troika' and public administration reform in Greece’, Journal of European Public Policy, 22 (3), pp. 295-314.

Floridi, L. (2018) 'Soft Ethics and the Governance of the Digital', Philosophy and Technology, 31(1), pp. 1-8. Available at: https://doi.org/10.1007/s13347-018-0303-9.

Floyd, J. (2014) 'Sense-making and acting for descent futures: Human and cultural pathways', Foresight, 16 (6), pp. 586-607. 
Gasova, K. and Stofkova, K. (2017) 'E-government as a quality improvement tool for citizens' services', Procedia Engineering, 192, pp. 225-230.

Ghourchian, S. and Yilmazkuday, H. (2020) 'Government consumption, government debt and economic growth', Rev Dev Econ, 24, pp. 589-605.

Glyptis, L., Christofi, M., Vrontis, D., Del Giudice, M., Dimitriou, S. and Michael, P. (2020) 'E-government implementation challenges in small countries: The project manager's perspective', Technological Forecasting and Social Change, 152, pp. 119880. Available at: https://doi.org/10.1016/j.techfore.2019.119880

Gray, A. and Jenkins, B. (2006) 'From public administration to public management: Reassessing a revolution', Research in public policy, analysis and management, 15, pp. 543-572.

Greek legislation (1997) Protection of the individual from the processing of personal data. Law, 2472/1997. Athens: The National Printing House.

Greek legislation (2007) Ratification of the Code of Status of Public Civil Servants and Employees of N.P.D.D. Law, 3528/2007. Athens: The National Printing House.

Greek legislation (2010) Enhancing Transparency with the Mandatory Posting of Laws and Acts of Government, Administrative and Self-Governing Bodies on the Internet "Clarity Program" and Other Provisions. Law, 3861/2010. Athens: The National Printing House.

Greek legislation (2017) Principles of Financial Management and Supervision (Integration of Directive 2011/85 / EU) - Public accounting and other provisions. Law, 4270/2017. Athens: The National Printing House.

Greek legislation (2019) Establishment, merger, renaming and abolition of Ministries and definition of their responsibilities - Transfer of services and responsibilities between Ministries. Presidential Decree 81/ 8-7-2019. Athens: The National Printing House.

Greek legislation (2019) Constitution of Greece. In the name of the Holy and Hummus and Indivisible Trinity. (Paragraph B of the Resolution of November 25, 2019 of the Ninth Revisionary Parliament of the Greeks). FEK, A 211/2019. Athens: The National Printing House.

Greek legislation (2020) Digital Governance (Transposition in Greek Law of Directive (EU) 2016/2102 and Directive (EU) 2019/1024) - Electronic Communications (Transposition in Greek Law of Directive (EU) 2018/1972) and other provisions. Law, 4727/2020. Athens: The National Printing House.

Grimmelikhuijsen, S., Jilke, S., Olsen, A. L. and Tummers, L. (2016) 'Behavioral public administration: Combining insights from public administration and psychology', Public Administration Review, 77 (1), pp. 45-56.

Gunawong, P. (2015) 'Open government and social media: A focus on transparency', Social Science Computer Review, 33(5): 587-598.

Gunawong, P. and Gao, P. (2017) 'Understanding e-government failure in the developing country context: A process-oriented study', Information Technology for Development, 23(1), pp. 153-178.

Halachmi, A. and Greiling D. (2013) 'Transparency, e-government, and accountability' Public Performance and Management Review, 36 (4), pp. 562-584. 
Hahamis, P., Iles, J. and Healy, M. (2005) 'E-government in Greece: Bridging the gap between need and reality’ Electronic Journal of e-Government, 3(4), pp. 185-192.

Hartmann, K. and Steup, C. (2015) 'On the security of international data exchange services for e-governance systems', Datenschutz und Datensicherheit - DuD, 39, pp. 472-476.

Heeks, R. and Stanforth, C. (2005) 'Understanding e-government project trajectories from an actor-network perspective', European Journal of Information Systems, 16, pp. 165-177.

Heusala, A-L. and Koistinen, J. (2018) “Rules of the game' in cross-border cooperation: Legal-administrative differences in Finnish-Russian crime prevention', International Review of Administrative Sciences, pp. 84(2), pp. 354-370.

Holzer, M. and Kim, S.-T. (2005) Digital governance in municipalities worldwide: A Longitudinal Assessment of Municipal Websites Throughout the World. E-Governance Institute, National Center for Public Productivity, 106.

Hu, G., Chohan, S.R. and Liu, J. (2020) 'Does IoT service orchestration in public services enrich the citizens' perceived value of digital society?' Asian Journal of Technology Innovation. DOI: 10.1080/19761597.2020.1865824.

I.I.A. The Institute of Internal Auditors (2020). Definition of Internal Auditing. Available at: https://na.theiia.org/standards-guidance/mandatory-guidance/pages/definition-ofinternal-auditing.aspx (Accessed 11 November 2020).

Iglezakis, I. (2008) 'The development of e-governance and the issue of digital inclusion in Greece with particular regard to the constitutional right of e-participation', Journal of Information, Law and Technology, 2008, 1, pp. 1-24.

Inkinen, T. (2012) 'Best practices of the Finnish government information society policy programme’, Transforming Government: People, Process and Policy, 6(2), pp. 167-187.

Introna, L., Hayes, N. and Petrakaki, D. (2010) 'The working out of modernization in the public sector: The case of an e-government initiative in Greece', International Journal of Public Administration, 33, pp. 11-25.

Jeannot, G., Van de Walle, S. and Hammerschmid, G. (2018) 'Homogeneous national management policies or autonomous choices by administrative units? Inter- and intracountry management tools use variations in European Central Government Administrations', Public Performance and Management Review, 41(3), pp. 497-518. Available at: https://doi.org/10.1080/15309576.2018.1442359

Katsonis, M. and Botros, A. (2015) 'Digital government: A primer and professional perspectives', Australian Journal of Public Administration, 74(1), pp. 42-52.

Keller, L.F. (2007) 'Public administration and the American Republic: The continuing saga of management and administration in politics. In J. Beck, W. B. Hildreth and G. J. Miller (Edit.) Handbook of public administration. Boca Raton: Taylor and Francis group, pp. 3-49.

Kontogeorgis, G. (2018) 'The role of internal audit function on corporate governance and management', International Journal of Accounting and Financial Reporting, 8 (4), pp. 1-15. 
Kontogeorgis, G. and Filos, J. (2012) 'The implementation of internal auditing in Greece', The South European Review of Business Finance and Accounting, 10, pp. 23-39.

Kuhlmann, S. and Jakel, T. (2013) 'Competing, collaborating or controlling? Comparing benchmarking in European local government', Public Money and Management, 33(4), pp. 269-276. Available at: https://doi.org/10.1080/09540962.2013.799815

Linan, F. and Fernandez-Serrano, J. (2013) 'National culture, entrepreneurship and economic development: Different patterns across the European Union', Small Bus Econ, 42, pp. 685-701.

Malodia, S., Dhir, A., Mishra, M. and Bhatti, Z.A. (2021) 'Future of e-Government: An integrated conceptual framework', Technological Forecasting and Social Change, 173, pp. 121102. Available at: https://doi.org/10.1016/j.techfore.2021.121102

Markellos, K., Markellou, P., Panayiotaki, A. and Stergianeli, E. (2014) 'Current state of Greek e-government initiatives', Journal of Business Systems, Governance and Ethics, 2(3). Available at: https://doi.org/10.15209/jbsge.v2i3.111.

Marshall, G. (2018) 'Making use of an enduring public administration myth. Refusal, subjective identification and the public interest', International Journal of Organization Theory and Behavior, 21 (3), pp. 150-157.

Mavroudeas, S. and Syriopoulos C. (2010) 'Testing convergence and divergence: The data from Greece', Journal of Applied Business Research, 14 (1), pp. 1-11.

McCue, C.P. and Pitzer, J. (2000) 'Centralized vs. decentralized purchasing: Current trends in governmental procurement practices', J. Of Public Budgeting, Accounting and Financial Management, 12 (3), pp. 400-420.

Ministry of Digital Governance. Mission of Ministry. Available at: https://mindigital.gr/ to-ypourgeio/apostoli. (Downloaded October 3, 2020).

Moeller, R. (2009) Brink's Modern Internal Auditing. NJ: John Wiley and Sons, Inc.

Moreno-Enguix, M.R., Lorente-Bayona, L.V. and Gras-Gil, E. (2018) 'Social and political factors affect the index of public management efficiency: A cross-country panel data study', Social Indicators Research, 144, pp. 299-313.

Murphy, J., Rhodes, M. L., Meek, J. W. and Denyer D. (2017) 'Managing the Entanglement: Complexity leadership in public sector systems', Public Administration Review, 77(5), pp. 692-704.

OECD. (2020) OECD Public Governance Policy Papers No. 03. Digital Government Index: 2019 results. Paris: OECD Publishing.

Panayiotou, N. and Stavrou, V. (2019) 'E A proposed maturity assessment framework of the Greek local government Web Electronic Services', Transforming Government: People, Process and Policy, 13 (3/4), pp. 237-256.

Patelis, K. (2020) 'Mind the 'Lag': The political economy of the internet in Greece' in Veneti, A. and Karatzogianni, A. (eds.) The emerald handbook of digital media in Greece: Journalism and political communication in times of crisis. Bingley: Emerald publishing, pp. 15-31. 
Pedersen, K. (2018) 'E-government transformations: challenges and strategies', Transforming Government: People, Process and Policy, 12(1), pp. 84-109.

Perez-Morote, R., Pontones-Rosa, C. and Nunez-Chicharro, M. (2020) 'The effects of e-government evaluation, trust and the digital divide in the levels of e-government use in European countries', Technological Forecasting and Social Change, 154 (119973), pp. $1-14$.

Philippidou, S.S., Soderquist, K.E. and Prastakos, G. P. (2004) 'Towards new public management in Greek public organizations: Leadership vs. Management, and the path to implementation', Public Organization Review: A Global Journal, 4, pp. 317-337.

Plesner, U. and Justesen, L. (2021) 'The double darkness of digitalization: Shaping digitalready legislation to reshape the conditions for public-sector digitalization', Science, Technology, and Human Values, 1-18. Available at: https://doi.org/10.1177/0162243921999715

Pownal, F. (2013) 'Public administration', in Beck, H. (ed.) A companion to ancient Greek government. Chichester: John Wiley and Sons Ltd, pp. 287-301.

Pyun, H.O. and Gamassou, C.E. (2017) 'Looking for public administration theories?', Public Organization Review, 18, pp. 245-261.

Schneider, D., Klumpe, J., Adam, M. and Benlian, A. (2020) 'Nudging users into digital service solutions', Electronic Markets, 30, pp. 863-881.

Singh, H., Grover, P., Kar, A.K. and Ilavarasan, P.V. (2020) 'Review of performance assessment frameworks of e-government projects', Transforming Government: People, Process and Policy, 14(1), pp. 31-64. Available at: https://doi.org/10.1108/TG-02-2019-0011

Somera, L.P., Lee, H-R., Badowski, G. and Cassel, K. (2016) 'Health information seeking, source trust, and culture: A comparative analysis of health information trends and needs between Guam and the United States', Journal of Health Communication, 21(4), pp. 469-478.

Spinellis, D., Vasilakis, N., Pouloudi, N. and Tsouma, N. (2018) E-government in Greece. Athens: diaNEOsis.

Spanoy, C. and Sotiropoulos, D. A. (2011) 'The Odyssey of administrative reforms in Greece, 1981-2009: A tale of two reform paths', Public Administration, 89 (3), pp. 723-737.

Tangi, L., Benedetti, M., Gastaldi, L., Noci, G. and Russo, C. (2020) 'Mandatory provisioning of digital public services as a feasible service delivery strategy: Evidence from Italian local governments', Government Information Quarterly, 38(101543), pp. 1-11.

Taylor, N.G. (2018) 'Youth information-seeking behavior and online government information: Tweens' perceptions of US federal government websites', Journal of Documentation, 74(3), pp. 509-525.

Torfing, J. (2019) 'Collaborative innovation in the public sector: The argument', Public Management Review, 21(1), pp. 1-11.

Trischler, J., Dietrich, T. and Rundle-Thiele, S. (2019) 'Co-design: From expert- to userdriven ideas in public service design', Public Management Review, 21(11), pp. 1595-1619. Available at: https://doi.org/10.1080/14719037.2019.1619810 
Tsakanikas, A., Danchev, S., Giotopoulos, I., Korra, E. and Pavlou, G. (2014) ICT Adoption and Digital Growth in Greece. Athens: Foundation for Economic and Industrial Research (IOBE). Available at: http://iobe.gr/docs/events/res_03_1062015_rep_eng.pdf. (Downloaded November 20, 2016).

Tumwebaze, Z., Mukyala, V., Ssekiziyivu, B., Tirisa, C. B. and Tumwebonire, A. (2018) 'Corporate governance, internal audit function and accountability in statutory corporations', Cogent Business and Management, 5(1), p. 1527054. Available at: https://doi.org/ 10.1080/23311975.2018.1527054

Twizeyimana, J. D. and Andersson, A. (2019) 'The public value of e-government - A literature review', Government Information Quarterly, 36(2), pp. 167-178. Available at: https://doi.org/10.1016/j.giq.2019.01.001.

United Nations (2020) E-government survey 2020. digital government in the decade of action for sustainable development. With addendum on COVID-19 response. New York: UN.

Van der Wal, Z., Van den Berg, C. and Haque M.S. (2021) 'Comparative public administration in a globalized World: Moving beyond standard assumptions toward increased understanding' Public Administration Review, 81(2), pp. 295-298.

Varotsis, N. (2019) 'Motivation in public autonomous organizations: The case of IAPR', OJBM, 7, pp. 1617-1636.

Varotsis, N. and Katerelos, I. (2018) 'Models of tax planning simulation: The case of Greece', Open Journal of Modelling and Simulation, 6, pp. 27-44.

Varotsis, N. and Katerelos, I. (2020) 'Tax behavior relating to the review of a revised regional tax policy: A study in Greece', Journal of Economic Structures, 9, pp. 7.

Venkatesh, V., Chan, F.K.Y. and Thong, J.Y.L. (2012) 'Designing e-government services: Key service attributes and citizens' preference structures', Journal of Operations Management, 30(1-2), pp. 116-133. Available at: https://doi.org/10.1016/j.jom.2011.10.001

World Bank. (2016) World Development Report 2016: Internet for Development. Berlin.

Wilson, T.D. (1999) 'Models in information behavior research', Journal of Documentation, 55 (3), pp. 249-270.

Wirtz, B.W. and Kurtz, O.T. (2016) 'Determinants of citizen usage intentions in e-government: An empirical analysis', Public Organization Review, 17, pp. 353-372.

Wirtz, B.W., Piehler, R. and Daiser, P. (2015) 'E-government portal characteristics and individual appeal: An examination of e-government and citizen acceptance in the context of local administration portals', Journal of Nonprofit and Public Sector Marketing, 27, pp. 70-98.

The article was submitted: 26.01.2021; approved after reviewing: 15.14.2021; accepted for publication: 28.11.2021. 